\title{
ФІЛОСОФСЬКИЙ ДІАПАЗОН АФОРИЗМІВ У ПСИХОЛОГІЧНІЙ РОЗВІДЦІ МАРІЇ МАТІОС «ЩОДЕННИК СТРАЧЕНОЇ»
}

Колоїз Ж. В. Філософський діапазон афоризмів у психологічній розвідці Марії Матіос «Щоденник страченої».

У статті йдеться про лінгвокреативний потенціал Марії Матіос, її здібності щодо продукування конструкцій, які з часом можуть (а деякі й уже змогли) відірватися від первинних контекстів і використовуватися як готові, відтворюватися за потреби в готовому вигляді в тій чи тій ситуації спілкування. Основний акцент зроблено на афоризмах, які ілюструють широкий філософський діапазон, виступають засобом світоглядних рефлексій, очевидно, не тільки головної героїні психологічної розвідки «Щоденник страченої». Авторські судження сфокусовано в художньо-семантичну площину поняттєвої сфери «буття», представлену ядерними та периферійними поняттями - «життя», «смерть», «людина», «жінка», «чоловік», «любов» і т. ін.

Досліджено семантико-психологічне навантаження афористичних висловлень, що рельєфно відбивають індивідуально-авторське розуміння людської сутності загалом і жіночої зокрема, зосереджують увагу на особливостях вербалізації уявлень про сучасний світ і місце жінки в ньому, образно актуалізують поняття «екзистенція», виокремлюючи передусім жіночу екзистенцію.

Ключові слова: афоризм, афористичне висловлення, судження, психологічна розвідка, семантичне наповнення.

Колоиз Ж. В. Философский диапазон афоризмов в психологическом исследовании Марии Матиос «Щоденник страченої».

В статье исследуется лингвокреативный потенциал Марии Матиос, ее способность продуцировать конструкции, которые со временем могут (а некоторые уже смогли) оторваться от первичных контекстов и использоваться в качестве готовых, воспроизводиться при необходимости в готовом виде в той или иной ситуации общения. Анализируются афоризмы, которые иллюстрируют широкий философский диапазон, выступают в качестве средства мировоззренческих рефлексий, по всей вероятности, не только главной героини психологического исследования «Дневник казненной». Авторские суждения рассматриваются в художественно-семантической плоскости понятийной сферы «бытие», представленной ядерными и периферийными понятиями, - «жизнь», «смерть», «человек», «женщина», «мужчина», «любовь» и т. д.

Определяется семантико-психологическая нагрузка афористических высказываний, которые рельефно отображают индивидуально-авторское понимание человеческой сущности в целом и женской в частности, фокусируют внимание на особенностях вербализации представлений о современном мире и месте женщины в нем, образно актуализируют понятие «экзистенция», выделяя прежде всего женскую экзистенцию.

(с) Ж. В. Колоїз, 2015. 
Ключевые слова: афоризм, афористическое высказывание, суждение, психологическое исследование.

Koloiz Zh. W. The range of philosophical aphorisms in the psychological exploration of "Shchodennyk strachenoyi" by Mariya Matios

This article reveals creative linguistic potential of Mariya Matios, her ability of sentences constructing, which over time can break away from the original contexts and be used as ready set expressions (though some of them already exist so). If necessary these statements can run themselves according to the communicative needs in various communicative situations. The paper itself focuses on aphorisms that illustrate the wide philosophical range. Aphorisms are obviously not only the means of ideological reflections of the main character in the psychological exploration of "Shchodennyk strachenoyi". The researcher's attention is paid on the literal and semantic plans of "existence" concept presented by the nuclear and peripheral concepts like "life", "death", "human", "woman", "man", 'love" etc.

The represented research investigates semantic and psychological senses in aphoristic statements that clearly reflect the individual author's understanding of human nature in general and the woman's nature in particular. These statements also point on the ways of verbalizing the ideas about the modern world and the place of women in it. Moreover aphorisms actualize the "existence" concept distinguishing first the female existence.

Key words: aphorism, aphoristic statement, opinions, psychological research, semantic content.

Мовотворчість Марії Матіос - це набуток не лише української, а й світової літератури (оригінальні прозові твори перекладено сербською, румунською, російською, японською і т. ін. мовами). Її письменницький доробок легко, вільно, просто, нестримно знайшов свого адресата, що зумів належним чином його оцінити. Це стосується передовсім художньої прози, яка отримала чимало позитивних відгуків (I. Андрусяк, Є. Баран, Я. Голобородько, Т. Дігай, Д. Дроздовський, К. Родик, Ю. Солод, М. Сулятицький, Т. Тебешевська, Р. Харчук та ін.) Про «вигострений, мов лезо, сюжет», «різьблено-красномовні деталі», «соковитий гуцульський колорит» (Ю. Джугастрянська), «психологічну напругу», «глибоке проникнення у мовну стихію» (В. Габор) і т. ін. сказано чимало.

Розмірковуючи про художні дилеми «взірцевої представниці «українських літературних регіонів», Я. Голобородько констатує: «Марія Матіос - класична соціумна письменниця, яка зовсім не байдужа до характеру, ритмічності, щільності своїх зв'язків із суспільством та свого іміджу в його рецепції-потрактуванні. Пречудово розуміючи, що новітній літпроцес - це як спорт, у якому 
для того, щоб триматися «на поверхні», необхідно показувати високі результати, вона абсолютно слушно чинить, коли 3 гордовитою постійністю нагадує соціуму про свої креативні інтенції, регулярно випускає власні тексти, тим самим беручи участь у літературному суперництві» $[1$, с. 66].

Марію Матіос поціновують і як митця, для якого важливий «не погляд із вузьконаціональних дзвіниць, а розмірковування в системі координат загальнолюдських гуманістичних цінностей» [5], і як особистість, що назавжди «сміливо i рішуче відкинула правила політичної обережності й суспільних табу» (П. Загребельний), бо мала тверде переконання: «завдання кожного письменника одне й те ж: писати, аби тебе зрозуміли» [5]. В одному зі своїх інтерв'ю письменниця зауважує: «Інколи мені здається: я помираю від журби та смутку тому, що ми не до кінця розуміємо одне одного навіть у себе вдома, i за межами теж зрозумілі не завжди. Але я намагаюся реставрувати історію не для того, аби ятрити рани. Навпаки. Я хочу, щоб вони якомога швидше загоїлися. Так, часто лікування пов'язане 3 надзвичайно сильним больовим шоком. Я хочу, аби мій читач пройшов через цей шок із думкою, що саме цей біль - а він інколи справді нестерпний, - примусить позбутися тягаря минулого, позбавить образ і необхідності помсти. Адже кожній людині властиво знати. А митцю властиво зображувати. Чим переконливіше зображення, тим благотворніший результат» [5].

Уміння «проникати в потаємні печери людської психіки» (В. Гутковський), підтримувати «соціумний інтерес» (Я. Голобородько) («прозові тексти М. Матіос презентують, моделюють, віртуалізують історії, що відбувалися з людиною, людьми, і подані густими, нерідко запашними шматками соціумного життя» [1 с. 66-67]) виокремили авторку 3-поміж багатьох у сучасному літературному процесі, створили «зірковий імідж» (К. Родик), забезпечили їй статус «бренда».

Творчий доробок письменниці, здебільшого художній простір так званих «хітів», став об'єктом зацікавлення цілої когорти науковців, передусім літературознавців (Л. Волошук. Н. Гаєвська, С. Жила, К. Ісаєнко, Н. Косинська, Л. Макаренко, К. Родик, С. Сипливець, С. Філоненко та ін.). У полі зору дослідників перебували як жанрове розмаїття прозових текстів авторки, жанрові модифікації, так і хронотоп, образи, сюжет, символіка, елементи психоаналізу і т. ін. 
певного твору чи творчого доробку загалом [7]. I лише подекуди 3'являлися окремі наукові розвідки, присвячені аналізові тих чи тих мовних особливостей (Г. Павлишин, О. Зелінська, Т. Тищенко та ін.). Утім, творчість Марії Матіос є благодатним матеріалом із позицій лінгвістичного аспекту дослідження. На цьому неодноразово наголошували принагідно, як-от: «Стиль М. Матіос відзначається багатством лексики, яка вміщує найрізноманітніші пласти: від фольклорного до книжного, від публіцистичного до просторічного, від рафінованого літературного до діалектного» [2, с. 12]. Авторка не лише художньо відображає навколишню дійсність, але й безпосередньо бере участь в оновленні та розбудові мовної системи. Добірність мови прозових текстів, забезпечується як лексичним, так і великою мірою афористичним багатством. I не тільки.

Мета запропонованої праці - дослідити філософський діапазон афоризмів, засвідчених в окремій психологічній розвідці «Щоденник страченої», виявити їхнє семантико-психологічне навантаження.

Невдовзі після того, коли психологічна розвідка «Щоденник страченої» побачила світ (2005), почала з'являтися і іiі літературна критика. У 2006 році Т. Тебешевська акцентувала: «Щоденник страченої» - книжка видана нещодавно, тож потребує читання, осмислення й аналізу як на рівні тематико-проблемному, жанровостильовому, так і образно-наративному» [8, с. 54]. Відтоді минуло майже 3 десяток літ, однак стверджувати сьогодні, що окреслені проблеми повністю успішно розв'язані, було б перебільшенням.

Як справедливо зауважує С. Філоненко, «сучасному критикові непросто визначити, на якому літературному полі працює авторка. Її «Націю», романи «Солодка Даруся», «Щоденник страченої», «Майже ніколи не навпаки» частіше розташовують на «високій полиці», тоді як книги «Бульварний роман», «Фуршет», «Містер і місіс Ю в країні укрів» визнають за «масові» [9, с. 80]. Продовжується дискусія не лише стосовно «масовості / немасовості» іï доробку, стосовно «маркування» іiі творів («жіночий кітч», «попса» і т. ін.), але й щодо модифікації жанрової належності.

Не викликає принципових заперечень, скажімо, твердження про те, що «Щоденник страченої» - $є$ «белетристичним» твором, адже «характеризується авторським вимислом», «повністю сформований авторською уявою» [4, с. 154]. До того ж, на думку О. Максименко, 
цю психологічну розвідку варто кваліфікувати як не просто як щоденник, а щоденник-імітацію, бо вона «цілком відповідає основним критеріям створення щоденника за змістом і за формою й окреслює ознаки щоденникової прози» [4, с. 155].

Якщо загалом дослідження «Щоденника страченої» 3 літературознавчих позицій можна вважати задовільним, то мовностилістичні особливості «психологічного трилера, у якому органічно поєднано сюжет і потік свідомості, дефективність розповіді i новелістичний фінал, тілесну чуттєвість і психоаналітику» (В. Гутковський) [6], так би мовити, залишилися «за кадром».

Натомість у цьому творі досить яскраво репрезентований лінгвокреативний потенціал письменниці, ऑii здібності щодо продукування конструкцій, які з часом можуть (а деякі й уже змогли) відірватися від первинних контекстів і використовуватися як готові, відтворюватися за потреби в готовому вигляді в тій чи тій ситуації спілкування, як-от: 1) Мабуть, навіки завойованих жінок, як інавіки завойованих територій, і справді немає; 2) Дні намі однакові, немов близнюки, і прісні, як тісто на лаваш; 3) Мудрість робить людину печальнішою; 4) Душевну драму в повсякденному житті, на жаль, не вважають справжньою катастрофою; 5) Нормальна людина завжди живе якщуо й не майбутнім, то тільки теперішнім; 6) Зазирання в минуле є способом злодійства, віднімання себе від себе; 7) Всі свої переваги людина може доводити за життя; 8) Дощз хоче зробити повінь тощо. Проілюстровані судження вирізняються глибокою змістовністю, семантичною наповненістю, смисловою завершеністю, утілені в образну, легку для запам'ятовування форму, виступають своєрідними естетичними знаками. Авторські висловлення мають узагальнювальний характер, використовуються для осмислення (й оцінювання) конкретних життєвих ситуацій, людських учинків, загальнолюдських цінностей і буття загалом.

Такі конструкції отримали в мовознавстві статус афоризмів, неодноразово піддавалися скрупульозному аналізові 3 різних позицій, зокрема й 3 погляду комунікативної i функціональної лінгвістики [3; 10]. Функціональна лінгвістика витлумачує афоризм як образне, логічно оформлене висловлення, для якого характерна стереотипність світобачення i поведінки, унаслідок чого він, як i власне паремія, є різновидом універсальної одиниці [3, с. 128].

(ㄷ) Ж. В. Колоїз, 2015. 
У психологічній розвідці афористичні висловлення слугують художнім засобом раціонально маніфестованих філософських позицій ïx авторки, яка «наголошує на можливості жінки в сучасному літературному просторі наполягати на своєму праві говорити й мати власну думку, творити художній світ жінки 3 позицій жінки» [8, с. 55].

Спродуковані у відповідний спосіб конструкції набувають глибокого філософського змісту, бо репрезентують систему ідей, поглядів на світ і місце людини в ньому, апелюють до споконвічної проблеми пошуку смислу буття: 1) Корона і крона життя - чекання смерті; 2) А ось і результат власного загартування: повільне чекання повільного вмирання; 3) Страждання невичерпні, поки в людині жевріє життя; 4) Але щзо правда - то правда: як себе поставиш, так навколо тебе ходитимуть; 5) Навіщзо люди иукають диявола? Ось він - ліворуч. Серцем називається; 6) Поспіх ніколи не є добрим порадником. Поспіх - той же страх, він паралізує навіть завчені рухи й думки; 7) Я боюся не минулого, а безодні, в якій воно помістилося; 8) Будь-яку стихію ми воліємо спостерігати в сусіда чи з телевізора.

Життя для письменниці - це не просто існування всього живого, це все пережите, зроблене людиною від піi народження i аж «останнього кінця»: 1) Але останнє - кінецьь життя - ие єдине, щзо позбавлене випадковості. Решта може й не відбуватися. I воно, як виявляється, далеко не безхмарне, бо сповнене болю, страху, страждання: 1) Життя і страждання - сіамські діти. I жоден найвправніший хірург не роз'єднає їх, не порушивши тієї гармонійної системи, яку заклала в них сама природа; 2) Іноді страх спогадів сильніший від повсякденних страхів.

У сучасному суспільстві змінилися пріоритети, людство переживає глибоку духовно-моральну кризу, пов'язану 3 економічними та соціальними перетвореннями, а відтак відбуваються зміни і в осмисленні багатьох філософських категорій: 1) Людство придумало й меценатствує зраді, брехні й обману; 2) Для пані Смерті сам проиес смерті - бізнес; 3) В мойй біді друг мого сердечного друга-мені не друг; 3) Єдине, щзо залишається непорушне, згадування; 4) На убивцюю знаходять іншого вбивцчю; 5) Люди навіщзось мордують одне одного із садистською витонченістю, ніби складають іспит на ремесло ката тощо. Проілюстровані зразки подекуди демонструють порушення валентнісних зв'язків між компонентами, 
що входять до складу відповідних суджень (пор.: наприклад, садизм «пристрасть до жорстокості, катування, насолода від страждання інших» і витонченість - «довершеність, досконалість»).

У психологічній розвідці Марії Матіос афоризми рельєфно відбивають індивідуально-авторське розуміння людської сутності загалом і жіночої зокрема, сфокусовують увагу на особливостях вербалізації уявлень про сучасний світ i місце жінки в ньому. Наприклад: 1) Люди - ие носї масок, а не облич. I незалежно, хто вони, де вони $i$ з ким; 2) Людина, а тим паче людина-жінка, не може мати більиого тоталітариста, гнобителя $і$ ката, ніж вона сама; 3) Жінка уже не може стати причиною чи каталізатором великомаситабної війни $і$ ввійти в світову історію, як вериителька мільйонів життів чи смертей; 4) Жінка проживає життя з очима винятково заплющеними тощо.

Афоризми авторки модифікують уявлення про людину «як суспільну істоту, що являє собою найвищий ступінь розвитку організмів, має свідомість, володіє членороздільною мовою, виробляє й використовує знаряддя праці», про особу «як утілення високих інтелектуальних і моральних цінностей»: 1) Вік-цุе досвід. Досвід не повинен би давати нормальній людині найменшого чансу з віком ставати розумовою мавпою, з мавпоподібними діями; 2) Людина істота настільки дивна, наскільки незрозуміла. Інакше, навіщуо б ій постійно вертатися в минуле - хай навіть лише безформними думками?; 3) Людина, яка звикає жити в малометражних примішеннях, набуває таких же форм тіла й такої ж скутості думок; 4) Роздвосна конкретною людиною свідомість нічим не відрізняється від розщепленої свідомості шизофреніка тощо. У межах авторських висловлень актуалізуються нові семи (скажімо, «суспільна істота, яка за певних умов здатна деградувати»).

Конкретизованого семантичного наповнення набуває й поняття «жінка»: це не просто «особа жіночої статі», а особа, яка прагне до матеріального життєзабезпечення та соціального самоствердження, попри те, що основне ऑiі призначення - продовження роду, а традиційна роль - «берегиня домашнього вогнища»: 1) Для нинішньої цчивілізації, щуо асоціюється винятково з чоловічою гегемонією, навіть мільйоннодоларова жінка важить не більше, аніж жінка в історіі Украӥни, в якій иілком гласно, але не так публічно, йй відведено роль () Ж. В. Колоїз, 2015. 
наложниці, а для офіщійних історичних опусів украӥнській жінці придумано роль безстатевої берегині; 2) Мій дім там, де мене чекають і хочуть, а як не чекають ніде, то я бездомна; 3) Жіниі важче позбутися власного життя, через те, щзо жінка майже завжди залишається оберегом іншого життя. Того, котре вона дала; 4) Жінка, котра понесла, - молодша від усіх молодих разом узятих. У такому разі натрапляємо й на деякі суперечності, як-от: з одного боку, спростовується роль жінки-берегині («придумано роль безстатевої берегині», з іншого, - ця роль утверджується («жінка майже завжди залишається оберегом іншого життя»).

Письменниця «спромоглася спроектувати жіноче несвідоме у творчість, передати його мовними категоріями, демонструючи власну суб'єктивність» [8, с. 57]. Ї̈̈ судження образно-метафоричні, емоційні, маніфестують «безодню людських станів і почуттів», гендерні стереотипи, як-от: 1) Людина людину бере в смертельну облогу своїх пристрастей, амбійій, бажань. I хто, якими грошима заплатить за цей марафон, за щзоденне випробування серия на розрив?; 2) Жіноче серие - сміттєзвалище. Запліснявіле, прогниле, необгороджене. Там є який завгодно непотріб, але немає нічого цілого, корисного чи функціонального; 3) Поки божевілля в будь-якій формі не торкнеться нас особисто, ми вдаємо, щзо не помічаємо тих, хто вражений цим лихом, мовчки ігноруючи, а то й зневажаючи вибраних; 4) Жіноче життя триває в придуманій нею темряві, там вона шукає своє правдиве зображення в дзеркалі якогось одного - вибраного нею чоловіка; 5) Найгірше, коли знаєш усе наперед. Живеш, ніби йдеш крізь прозору стіну рентгенівського проміння - $і$ бачиш усе, про щзо інші навіть і не здогадуються; 6) Сдине, що залишається непорушне, згадування; 7) Ніхто не думає, щуо чергова пристрасть - остання.

В епіцентрі жіночих роздумів, безумовно, знаходиться «особа протилежної статі». Лексема «чоловік» (пор.: «великий перець великого міста») доволі часто вводиться у структуру афористичних висловлень: 1) Усі чоловіки такі - вони роздягають жінку очима швидше, аніж вона встигне привітатися; 2) Чоловік, який думає, щзо жіночий плач за ним - че щзастя... Хай він собі буде здоровий; 3) Чоловік - ие короткочасна жіноча примха, яка з примхливої волі жінки стає ї̈ довгограючою проблемою; 4) Усі чоловіки - діти. I кожна жінка на планеті закінчує тим, щуо всиновлюе їх; 5) Все, щуо 
робить жінка в житті, - вона робить лише для себе. А для иього жінка тримає поруч себе своєрідний підручний матеріал - чоловіка, щุо волею судьби чи тимчасової примхи вигулькує на ї̈ иляху; 6) Жіноча свідомість малопридатна саме для тоталітарних репресій, або придатна менше через те, щз жінка завжди більш відповідальна за життя, ніж чоловік; 7) Чоловіки - вони мастаки інтриги не менші, аніж хвалені, завжди інтуїтивні жінки. Здебільшого такі конструкції грунтуються на протиставленні, що забезпечується передусім лексичною антонімією (чоловік - жінка). Вони інтимізують оповідь, бо допомагають розібратися в жіночій психології й у іï стосунках із чоловіком, створюють відповідну мовну тональність.

Жіночі психічні й фізичні відчуття відмінні від чоловічих: жінки й чоловіки по-різному сприймають навколишній світ, усвідомлюють естетичні цінності, емоції, що супроводжують оцінку певних суспільних подій, по-різному виявляють почуття глибокої сердечної прив'язаності до іншої статі, те почуття, яке люди віддавна називають любов’ю. I це цілком очевидно. «Відповідна до фемінного типу мислення, проявленого в тексті, і модель головної героїні, - зауважує T. Тебешевська. - За таким стереотипом, жінка не може бути самостійною і сильною настільки, щоб не потребувати чоловіка в ролі постійно присутньої «непорушної стіни», за яку можна сховатися й на яку можна опертися. Жіноча природа також не може бути «закрита» в монастирі, адже душа й тіло прагне любити й отримувати любов навзаєм» [8, с. 61].

Сучасна жінка, сповідуючи свободу й незалежність, водночас хоче кохати й бути коханою, бути дружиною і матір'ю (але не коханкою, не «прихованою дружиною»), мати повноцінне щастя, аби не перетворити своє життя на «повільне чекання повільного вмирання» (пор.: у філософії життя саме лексема «любов» виступає синонімом до слова «життя»; любити - значить жити). Однак любов це залежність, передусім почуття глибокої сердечної прив'язаності до іншої статі: 1) Люди, які відчувають одне одного без слів, - уже залежні навіки. Якщо вони самі про це собі не наважуються казати, їм скажуть інші; 2) Позбавлений сентиментів чоловік, чоловік із знаннями й упевненістю того, щзо його кохає жінка, зобов'язаний тримати ї̈ на прив'язі з не меншою кмітливістю, ніж тримає публіку пройдисвіт, авантюрист чи шулер. Це пристрасть, сильна, бурхлива, (с) Ж. В. Колоїз, 2015. 
нестримна у своєму виявленні. А подекуди й не контрольована, бо спопеляє і душу, і тіло. До того ж немає законів, згідно з якими та чи та жінка повинна любити саме того чи того чоловіка: любов не пояснюється ні фізіологічними, ні психологічними, ні фізичними чинниками людського буття.

У такому разі афоризми, засвідчені у психологічній розвідці, маніфестують любов не стільки як особливий індикатор духовності, скільки як девальвацію відповідної цінності: 1) I кожен живе таким своїм обманом, як правдивою - щуонайравдивішою - правдою, бо поки людина не спізнала любові, вона їй привиджується в кожному стрічному. I тому кожен із нас іде за кожною новою любов'ю, як за марою, щзоб зловити ї̈ і нарешті заспокоїтися; 2) Колись він хотів стати власником моїх думок. А йому дозволялося мати тільки тіло; 3) Любов - вона безконечна. Людина може любити, скільки завгодно разів. I кожного разу по-іншому. I щзоразу - вперше; 4) Любов - ие один день, один кусень хліба, одне горня води. Хіба ти за одним куснем можеш пізнати повний його смак чи набутися одним днем верем'я?; 5) Може, любов - суиільна помста за не реалізоване колись із кимсь іншим шаленство - $i$ більше нічого?! Письменницькі афористичні висловлення, їхнє семантичне наповнення дають змогу констатувати: любов - це велика таїна, бо має приховану внутрішню сутність, вона приваблива своєю загадковістю, попри те, що, на перший погляд, нібито й лежить на поверхні, «не приховується від інших», «відома всім».

Любов як універсальна філософська категорія, що фіксує у своєму змісті глибоко індивідуально-вибіркове інтимне почуття, змінює одновекторні суб’єкт-суб'єктні відношення на кількавекторні. Пропагування «вільних» стосунків пояснюється дуже просто: Людству невигідно проповідувати сталість, стабільність, плекати, леліяти, колисати, щзо там іще з ним робити, щоб уберегти тривке кохання двох. Адже: Шалене кохання грошей не додає і щуастя не примножує. Водночас, любов - це не лише пристрасть, утіха, хіть, самопожертва, примха, сентименти, а й самотність, страждання і чекання: 1) Господи, за щзо ж ти так не любиш жінку, щзо даєш їй муку невиправданого чекання?; 2) Чекання нестерпне, як нічний зубний біль тощо. Звідси, відповідно, й оновлення системи мовно-ціннісних координат, модифікація художньо-семантичного наповнення: 1) Людство засвоїло 
так багато знань, зробило винаходи, вивчило так багато слів, довчає Всесвіт - а не знає елементарних речей: не знає процесу розлюблення одною людиною іншої; 2) Будь-яке душевне потрясіння, непрогнозоване хвилювання - иее електричний струм для вразливої душі. Як правило, такий струм не вбиває, а лише струшує приспану енергію, стимулює до життя заржавілі сили волі; 3) Чоловік зневажає жінку навіть тоді, коли любить. Він ненавидить свою слабкість біля неї; 4) Кмітливість зневоленої пристрастю жінки може конкурувати з розрахунками фізиків-теоретиків. Чимало авторських суджень маніфестують певну парадоксальність. Це й не дивно, оскільки сама любов є парадоксальною за своєю суттю. 3 одного боку, заради любові жінка здатна подолати будь-які перешкоди, 3 іншого, - любов межує зі смертю, бо деякі 3 цих перешкод виявляються непосильними: 1) Маску можна зірвати, як присохлий до свіжсї рани бинт, - силою болю. Або силою смерті; 2) Кохання - лише найвидатніша пожиттєва маска людини. Усі проілюстровані афоризми відтворюють реалії буття в оригінальній, екстраординарній формі. Своєрідної образної трансформації зазнають як лексеми кохання, любов, так і лексеми розлюблення, потрясіння, пристрасть, примха, свідомість і т. ін.

Досліджуваний фактичний матеріал переконливо засвідчує: любов - категорія дискусійна, іiі «величину» можна «вимірювати» крізь призму різних семантичних площин. Крім того, люди здебільшого лише думають, що їм судилося пізнати любов, в основному задовольняючись її підробкою, імітацією.

Репрезентовані афористичні висловлення образно актуалізують поняття «екзистенція», виокремлюючи передусім жіночу екзистенцію, осмислюючи яку, авторка продукує конструкції, здатні до мовноестетичного функціонування й за межами запропонованого твору. Такі конструкції вирізняються досконалою формою і завершеним змістом.

Афоризми ілюструють широкий філософський діапазон, виступають засобом світоглядних рефлексій, очевидно, не тільки головної героїні. Авторські судження сфокусовані в художньосемантичну площину поняттєвої сфери «буття», представлену ядерними та периферійними поняттями - «життя», «смерть», «людина», «жінка», «чоловік», «любов», «самотність» і т. ін.

( Ж Ж. В. Колоїз, 2015. 
Для реалізації загальної смислової ідеї залучені афоризми, грунтовані на різних мовностилістичних засобах: письменниця вдало «експлуатує» стилістичні ресурси, афоризми ілюструють зразки використання і стилістичних тропів, і стилістичних фігур (метафора, епітет, порівняння, антитеза, оксюморон, паралелізм і т. ін.). Вони можуть стати предметом дослідження іншої наукової праці. До того ж індивідуально-авторські судження, засвідчені у психологічній розвідці «Щоденник страченої», як i афористичний корпус Марії Матіос загалом, викликають зацікавлення не лише 3 позиції семантикосмислової, а й структурно-композиційної та інтенційно-прагматичної природи.

\section{Література}

1. Голобородько Я. Буковинська орнаментика Марії Матіос / Я. Голобородько // Вісник НАН України. - 2008. - № 3. - С. 66-73.

2. Ісаєнко К. П. Стилістичні особливості прози О. Забужко та М. Матіос (спроба порівняльного аналізу) / К. П. Ісаєнко // Наукові записки НДУ ім. М. Гоголя : Філологічні науки. - 2012. - С. 12-14.

3. Колоїз Ж. В. Українська пареміологія : [навчальний посібник] / Ж. В. Колоїз, Н. Н. М. Шарманова ; за ред. Ж. В. Колоїз. - [2-е вид.. стереотип.]. - Кривий Ріг : КПІ ДВНЗ «КНУ», 2014. - $349 \mathrm{c.}$

4. Максименко О. В. «Щоденник страченої» Марії Матіос - щоденник-імітація / О. В. Максименко // Вісник ЛНУ імені Тараса Шевченка. - 2013. - Ч. II. - №4 (263). C. $154-160$.

5. Матіос М. Не знаю жодного читача, який би оскаржував правду часу в моїй «Нації» / М. Матіос // Дзеркало тижня. - 2008. - №9 [Електронний ресурс]. - Режим доступу : http://gazeta.dt.ua/SOCIETY/mariya_matios_ne_znayu_zhodnogo_chitacha_ yakiy_bi_oskarzhuvav_pravdu_chasu_v_moyiy_natsiyi.html

6. Матіос М. Щоденник страченої / М. Матіос. - [Електронний ресурс]. - Режим доступу : http://lib.sumdu.edu.ua/library/docs/Books/Matios_Shchodennyk_strachenoi.pdf

7. Насмінчук I. А. Проза Марії Матіос: особливості індивідуального стилю : автореф. дис. ... канд філолог. наук / І. А. Насмічук, 2009. - 16 с.

8. Тебешевська Т. Художні особливості «Щоденника страченої» Марії Матіос / Т. Тебешевська // Слово і час. - 2006. - № 2. - С. 54-62.

9. Філоненко С. О. Роман із владою (гендерні аспекти прози Марії Матіос i Тетяни Устінової) / С. О. Філоненко // Вісник ЗНУ : Філологічні науки. - 2009. - №2. - C. $78-86$.

10. Шарманова Н. М. Українська афористика : структурно-семантичний та функціональний аспекти : дис. ... канд. філол. наук / Н. М. Шарманова. - Кривий Ріг, 2005. -217 c.

Стаття надійшла до редакиії 09.02.2015 p. 